\title{
Market Competition, Station Ownership, and Local Public Affairs Programming on Broadcast Television
}

\author{
Michael Zhaoxu Yan ${ }^{1} \&$ Philip M. Napoli ${ }^{2}$ \\ 1 Department of Communication Studies, University of Michigan, Ann Arbor, Ml 48104-2523 \\ 2 Graduate School of Business \& The Donald McGannon Communication Research Center, Fordham University, \\ New York, NY 10023
}

This study examines the relationship between competitive conditions in television markets, ownership characteristics, and commercial broadcast television station provision of local public affairs programming. The results from an analysis of a random sample of 285 fullpower television stations showed that half of the stations in the sample did not air any local public affairs programming during the 2-week sample period. Among the study's other findings are that competitive conditions and station financial resources do not necessarily increase the provision of local public affairs programming and that ownership characteristics bear little meaningful relationship to local public affairs programming provision.

doi:10.1111/j.1460-2466.2006.00320.x

In the U.S. system of broadcast regulation, the provision of locally produced informational programming traditionally has been considered an important component of a station's fulfillment of its obligation to serve the public interest (Federal Communications Commission [FCC], 1999b), with informational programming generally defined as local news and public affairs programming. It is through the provision of such programming that stations are able to serve the informational needs and interests of their local communities.

This localism principle refers to media policy makers' long-standing commitment to assuring that media services effectively serve and reflect the needs and interests of local communities-as opposed to having a primarily national or regional orientation in the services that they provide (FCC, 2004). The manifestation of this principle at one point took the form of specific FCC-imposed requirements for minimum levels of local news and public affairs programming (FCC, 1976). The FCC traditionally has operated under separate definitions of news and local public affairs programming. The commission has defined public affairs programming (the focus of this analysis) as "programs dealing with local, state, regional, national or

Corresponding author: Michael Zhaoxu Yan; e-mail: zyan@umich.edu. 
international issues or problems, documentaries, minidocumentaries, panels, roundtables and vignettes, and extended coverage (whether live or recorded) of public events or proceedings, such as local council meetings, congressional hearings and the like" (FCC, 1984, p. 172). News programs, on the other hand, have been defined by the commission as "reports dealing with current local, national and international events, including weather and stock-market reports, and commentary, analysis, or sports news when they are an integral part of a news program" (FCC, 1984, pp. 171-172).

The FCC's news and public affairs programming requirements were eliminated in the 1980s under the presumption that unregulated markets would effectively produce a broad range of program types and serve a broad range of audience interests and concerns (FCC, 1984). However, the fact that the FCC no longer has explicit local news and public affairs programming requirements does not mean that the commission no longer is concerned with the extent to which stations provide such informational programming. The commission's current position is that stations must provide some programming that serves the informational needs of their communities in order to fulfill their public-interest obligations (FCC, 1999a). Moreover, the provision of local news and public affairs by television stations remains central to the FCC's definition of the number of voices in a media market (see Singleton \& Rockwell, 2003). This perspective of the FCC has recently been reinforced by the Prometheus Radio Project v. Federal Communications Commission (2004) court that remanded much of the FCC's 2003 decision to relax a number of media ownership regulations. In its decision, the court concluded that the commission had erred in including the Internet as a distinct information source for the purposes of calculating its diversity index because the Internet, unlike broadcast television and other traditional media, does not yet represent a significant source of local news and information (Prometheus Radio Project v. Federal Communications Commission).

Concerns about whether broadcast stations adequately serve the needs and interests of their local communities via the provision of informational programming have arisen in a variety of recent policy contexts, as have questions about appropriate regulatory mechanisms for promoting the production of such programming. Central to these policy deliberations is the question of the relationship between competitive conditions, ownership characteristics, and the provision of informational programming. For instance, in connection with the commission's ongoing inquiry into whether the transition to digital broadcasting merits rethinking broadcasters' public-interest obligations, the commission asked, "are there sufficient marketplace incentives to ensure the provision of programming responsive to community needs, obviating the need for additional requirements?" (FCC, 1999a, p. 29). In the commission's 2002 review of media ownership regulations, one key line of inquiry in the ownership proceeding involved whether the local orientation in media content bore any systematic relationship to the characteristics of the owners of media outlets or to the competitive conditions in media markets (see FCC, 2002, 2003). Thus, the commission conducted a study examining the relationship between ownership 
and the provision of local news and public affairs programming (Spavins, Denison, Roberts, \& Frenette, 2002), the results of which contributed to the commission's decision to relax cross-ownership and national broadcast cap regulations (FCC, 2003).

The most recent appearance of the local informational programming issue involved the commission's issuance of a notice of inquiry on broadcast localism (FCC, 2004), in which the commission sought guidance on the extent to which broadcasters effectively serve the needs and interests of their local communities and on whether any alterations in existing regulations were necessary to assure such service. In this notice, the commission returned to the questions raised in the digital television proceeding, seeking information on "how effectively have market forces fulfilled the goal of ensuring that broadcasters air programming responsive to the needs and interests of their communities" (FCC, 2004, p. 5).

Unfortunately, prior research on the relationship between competitive conditions, ownership characteristics, and the provision of informational programming is quite dated and/or suffers from a variety of methodological shortcomings. This study is an effort to improve upon the weaknesses of the earlier work and provide a thorough and representative analysis of how competitive conditions and station ownership characteristics are related to the provision of local public affairs programming.

\section{Localism: Influences of ownership structures and competition}

The study of media performance, particularly in policy-related contexts, inevitably involves the intersection of economic and noneconomic perspectives on media markets (see Entman \& Wildman, 1992). Thus, when we consider broadcast stations' provision of local public affairs programming, we inevitably must draw upon economic theory and consider the potential impact of competition and economies of scale on programming output. It is well understood that there can be significant economies of scale in the production of media products, particularly given that media products are characterized by high first-copy costs and relatively low marginal costs (Owen \& Wildman, 1992). From this standpoint, organizational structures that facilitate the exploitation of economies of scale in content production may facilitate greater production of programming such as news and public affairs. Advocates of greater ownership concentration frequently emphasize the benefits that can be derived from the economies of scale that can be achieved by allowing media owners to expand their holdings (e.g., Karmazin, 2001). Large station group owners may, for instance, be able to convert the economies of scale presumably derived from group ownership into greater amounts of local news and public affairs programming (see FCC, 2003; Karmazin, 2001).

To the extent, however, that the focus of this study is on local programming, it is questionable whether such economies of scale can be achieved across stations in different markets, when the programming at issue is being produced exclusively for a single local market. This may explain why, up to this point, there has been 
relatively little consistent evidence of a meaningful relationship between station group ownership or station group size and the provision of informational programming (Napoli, 2002, 2004; Napoli \& Yan, in press; Spavins et al., 2002; Wirth \& Wollert, 1979).

Duopoly ownership (ownership of two stations within a single market) presents a more compelling context in which we might expect economies of scale to manifest themselves in the form of greater provision of local informational programming. Duopoly scenarios - in which a company owns two stations in a local television market-have become increasingly common due to relaxed ownership regulations in recent years (see FCC, 1999c, 2003). One prominent argument in support of this decision was that the relaxed rules would allow the commonly owned stations to operate more efficiently by taking advantage of their combined resources, which would lead to increased informational programming. Much of the evidence in support of this assumption is, at this point, primarily anecdotal (see FCC, 1999c), though an econometric analysis prepared for Sinclair Broadcasting found that common ownership led to a small increase in the probability that a station would cover local news at all, but there was no statistically significant difference in terms of the amount of news provided (Crandall, 2003). More recent research, however, found a negative relationship between duopoly ownership and local news provision (Napoli \& Yan, in press).

A focus on the economic theory relevant to media content production also raises the issue of the relationship between competition and the provision of local public affairs programming. Proponents of a marketplace approach to broadcast regulation frequently have advocated that competition is capable of encouraging the production of socially beneficial programming such as news and public affairs (e.g., Fowler \& Brenner, 1982). From this standpoint, more competitive market conditions should encourage greater production of informational programming. Previous research suggests that the intensity of competition from competing program sources (e.g., cable, public television) may increase a commercial station's news and public affairs programming output as stations respond to the program offerings of their competitors (Powers, 2001). Previous research also has found a statistically significant, though weak, positive relationship between the number of commercial broadcast stations in a market and the provision of local public affairs programming (Napoli, $2001 b$ ), suggesting again that increased competition may, in fact, promote the production of such programming.

It also, however, may be the case that as a media market grows more competitive, content providers may establish specific programming niches for themselves and cede certain program types to their competitors in an effort to differentiate themselves (see Hamilton, 2004; Napoli, 2004). Thus, in the public affairs programming context, it may be that the growth of cable television and noncommercial stations in a market may lead broadcasters to offer less local public affairs programming as broadcasters may cede that programming category to their cable and noncommercial competitors. 
Economics alone, however, is not sufficient for explaining the behavior of media organizations, which operate simultaneously as both economic and political/cultural institutions (Napoli, 1997). In the local public affairs programming context being analyzed here, the concept of localism provides perhaps the most obvious starting point for establishing a sociopolitical theoretical perspective for understanding media performance. Although policy makers and researchers tend to consider localism primarily as normative policy principle (see Napoli, 2001a), in reality, localism is reasonably well developed from the standpoint of predictive theory. It is in fact possible to articulate a predictive theory of localism that has underscored FCC's policy making and policy advocacy for many years. To the extent that the policy makers have, for decades, emphasized a local orientation to the structure and regulation of our media system (Napoli, 2001a), it is based on certain predictive propositions about the relationship between a local orientation to media market structure and media performance-specifically, that a stronger local orientation in media market structure will produce better service addressing the particular needs and interests of individual local communities due to locally based owners' stronger community ties and greater knowledge of these needs and interests (Napoli, 2001a; Ryan, 2001). This argument has, unfortunately, seldom been put to the test; however, a study by Napoli (2002) did examine this issue and found a significant positive relationship between local ownership and the provision of public affairs programming. This relationship, however, only held true when local and nonlocal public affairs programming were included in the analysis simultaneously and dissipated when local public affairs programming was analyzed exclusively.

From a localism perspective, ownership by large ownership groups represents a disconnect from the local community and therefore may result in less commitment to serving local community needs and interests. Similarly, affiliation with national broadcast networks may undermine the extent to which local media outlets are truly locally controlled and thereby may contribute to lower levels of service to the informational needs and interests of local communities. Some industry stakeholders have argued that network owners-particularly the Big Four (ABC, NBC, CBS, and FOX) network owners-are particularly insensitive to community needs and therefore are negligent in serving the public interest (Network Affiliated Stations Alliance, 2001). This insensitivity and negligence may be reflected in these stations' commitment to local news and public affairs programming.

As should be clear, there are areas where economic theory and the localism principle may conflict. For instance, from an economic standpoint, local ownership may be highly inefficient, with these inefficiencies leading to less, as opposed to more, programming addressing the needs and interests of local communities (i.e., local public affairs programming). From a localism perspective, greater commitment to serving the needs and interests of the local communities is not likely to arise from economic incentives but rather from the strength of community ties and commitment that arise from the proximity between the media outlet owner and the community served by the media outlet. 
Ultimately, the issues raised in this discussion-particularly in terms of how they relate to the provision of local public affairs programming-coalesce around two broad research questions:

RQ1: Is there a relationship between competitive conditions in a media market and broadcast stations' provision of local public affairs programming?

RQ2: Is there a relationship between broadcast station ownership characteristics (i.e., ownership group size, local ownership, network ownership, duopoly ownership) and the provision of local public affairs programming?

\section{Methodological issues}

It is important to recognize that much of the research on the factors affecting informational programming provision is quite dated (e.g., Chamberlin, 1979; FCC, 1984; Wirth \& Wollert, 1978, 1979). The question of the quantity of informational programming that a station provides was a much more prominent research issue in the era when the FCC applied explicit performance standards. Another shortcoming of much of this early work is that it relied primarily upon station self-reports of their programming practices-a somewhat questionable research strategy considering the documented tendencies by stations to misrepresent their programming practices when reporting to regulators or researchers operating on their behalf (Kunkel, 1998).

Much of the more recent research forming the basis of this literature review has employed alternative methods (such as content analysis of station program schedules/descriptions or reliance on commercial scheduling data sources that may be more reliable than station self-reports) but still suffers from a number of important shortcomings. These include the failure to employ rigorous sampling procedures (e.g., Spavins et al., 2002) and to incorporate the full range of relevant explanatory factors (e.g., Napoli, 2001b). For instance, the FCC's recent study (Spavins et al., 2002) examined all programming in November 2000 for affiliates of the Big Four network in those markets in which at least one "owned and operated" station existed. From a sampling standpoint, there are a number of fairly clear shortcomings in this data set. First, the reliance on data for November is somewhat problematic in that November is a "sweeps" month, when station programming practices frequently deviate from the norm (Ehrlich, 1995). ${ }^{1}$ Second, the rather unusual decision to focus only on Big Four network affiliates, and only on those affiliates in markets in which one owned and operated station is present, limits the generalizability of the results to the broader population of broadcast stations. This study also failed to account for a variety of station and market characteristics that previous studies have found to be related to the provision of news and public affairs programming and also failed to differentiate between news and public affairs programming in its analyses. Similarly, Napoli's study focused on market-related factors, to the neglect of potentially relevant ownership factors. 
This study attempts to address these weaknesses by (a) utilizing a randomly selected sample of stations, (b) employing a randomly constructed 2-week sample of station programming, and (c) simultaneously accounting for station ownership and market competition characteristics.

\section{Method and variables}

This study analyzes a 2-week constructed sample of broadcast television programming in 2003 for a sample of 289 full-power U.S. television stations. The specific days comprising the sample 2 weeks were randomly selected. The station sample frame is a list of 1,447 full-power, English-language television stations published in the Nielsen Station Index Directory of Television Stations 2003-2004. The stations were ordered first by the rank of their television market (from the highest to the lowest rank) and then alphabetically within each market. Every fifth station was drawn, with the starting point randomly determined. Four stations were excluded for various reasons. ${ }^{2}$

Data for the station and market independent variables used in this study were obtained from the 2003 Investing in Television Market Report (4th ed.) and the 2003 Investing in Television Ownership File (3rd ed.), both published four times a year by BIA Research (2003a, 2003b). The competitive conditions in a station's market were assessed by creating variables capturing the number of commercial and noncommercial stations in a station's market, cable television penetration, and the audience share for public and nonbroadcast television in the market. These variables are intended to capture both the number and the competitive strength of the alternative program sources against which any broadcast station must compete, all of which might impact the extent to which a station chooses to offer local public affairs programming.

Ownership characteristics incorporated into this study included whether the station was a duopoly, whether the station was owned locally, whether the station was owned by one of the Big Four broadcast networks, and the size of the station group owning the station (as measured by the group's national household reach). These variables are intended to capture the primary station ownership characteristics that have been of interest to policy makers and that frequently have been asserted to bear some relationship to the provision of local public affairs programming, from both economic theory and localism theory perspectives.

A number of control variables were included in the study as well. First, because many public affairs programs are focused around minority interests and concerns, the extent to which minorities comprise a significant portion of a station's potential audience may compel stations to provide more local public affairs programming. Thus, the percentage of the population of the station's market that is White was included as a control variable. A station's financial resources (as measured by its previous year's revenues) also were included as a control variable. Stations with greater financial resources may be more inclined to provide local informational programming, given the greater costs associated with producing original locally 
oriented content, as opposed to purchasing syndicated content. This perspective has found support in previous research (see FCC, 1984; Napoli, 2004; Wirth \& Wollert, 1979). A station's status as a very high frequency (VHF) or ultra high frequency (UHF) broadcaster was included as a control variable as well. Although the diffusion of cable has dramatically reduced the UHF handicap, VHF stations tend to still be more widely viewed and more successful than their UHF counterparts-a fact reflected in the FCC's continued policy of applying a 50\% discount on the audience reach of UHF stations toward the national television ownership cap. This may impact a station's likelihood of investing in informational programming. Market size (in terms of the number of television households in the market) also was included as a control variable to account for the possibility that stations' programming practices vary according to the size of their potential audience. A final control variable that was employed was whether a station was a Big Four network affiliate. These affiliates, although financially strong, relinquish the most time to their parent network and therefore may have less time to devote to local informational programming, particularly given that the Big Four networks provide their local affiliates with national public affairs programming (e.g., Meet the Press, Face the Nation). A full description of all the independent variables employed in the study is given in Table 1.

For each sampled station, a constructed 2-week sample of programming schedules was obtained from Tribune Media Services (operator of the zap2it.com online television program schedule database). The sample dates are as follows: January 11 (Saturday), January 22 (Wednesday), February 17 (Monday), February 27 (Thursday), March 23 (Sunday), March 28 (Friday), April 22 (Tuesday), August 11 (Monday), September 30 (Tuesday), October 18 (Saturday), November 5 (Wednesday), November 6 (Thursday), November 9 (Sunday), and November 28 (Friday), all of 2003. The construction of a composite program sample from days of the week throughout the year was to control for possible effects from idiosyncrasies associated with particular months or weeks within the year (e.g., sweeps period, election periods, or particularly active news weeks) (see Bishop \& Hakanen, 2002). In addition to operating the online schedule database (which only provides scheduling information for the current 2-week period), Tribune provides detailed television program schedule data to commercial and noncommercial clients. For this study, 18 fields of data were obtained, ranging from station call letters to the date, time, title, description, and duration of program broadcasts. The data set also contained a number of useful descriptive fields that together helped create the dependent variable for this study - the total minutes of local public affairs programming provided by each station in the sample over the 2-week time period (see Table 1). The "program type" field classified each program according to a wide range of programming types, including public affairs. More detailed gradations were contained in the "category" field, which again included public affairs. The data set also included a "program origination" field, which identified each program as "local," "syndicated," or "network" (along with identifying the originating network). This data field facilitated identifying local versus national public affairs programming. This study focused on local 
Table 1 Variable Names and Descriptions

\begin{tabular}{|c|c|c|c|}
\hline Variables & Definitions & $M$ & $S D$ \\
\hline $\begin{array}{l}\text { Local public affairs } \\
\text { (dependent variable) }\end{array}$ & $\begin{array}{l}\text { Amount of local public affairs } \\
\text { programming broadcast by a } \\
\text { commercial station during } \\
\text { the } 2 \text {-week sample period } \\
\text { (in minutes) }\end{array}$ & 42.79 & 87.68 \\
\hline \multicolumn{4}{|l|}{$\begin{array}{l}\text { Station and ownership } \\
\text { independent variables }\end{array}$} \\
\hline VHF/UHF & $\begin{array}{l}\text { Whether a station is a } \\
\text { VHF or UHF station } \\
(1=V H F ; 0=U H F)\end{array}$ & 0.46 & 0.50 \\
\hline Station revenues & $\begin{array}{l}\text { Annual station revenues } \\
\text { in } 2002 \text { (in millions) }\end{array}$ & 20.22 & 31.09 \\
\hline Big Four & $\begin{array}{l}\text { Whether a station is a Big } \\
\text { Four affiliate }(\mathrm{ABC}, \mathrm{NBC}, \mathrm{CBS} \text {, } \\
\text { FOX; } 1=\text { yes; } 0=n o)\end{array}$ & 0.71 & 0.45 \\
\hline Duopoly & $\begin{array}{l}\text { Whether a station is local duopoly } \\
\qquad(1=y e s ; 0=n o)\end{array}$ & 0.18 & 0.39 \\
\hline Big Four ownership & $\begin{array}{l}\text { Whether a station is owned } \\
\text { by a Big Four broadcast } \\
\text { network }(1=\text { yes; } 0=n o)\end{array}$ & 0.11 & 0.32 \\
\hline National audience reach & $\begin{array}{l}\text { Percentage of national } \\
\text { TV households reached } \\
\text { by a station's parent company }\end{array}$ & 0.13 & 0.18 \\
\hline \multicolumn{4}{|l|}{ Market independent variables } \\
\hline TV households & $\begin{array}{l}\text { Number of TV households in a } \\
\text { station's market (in millions) }\end{array}$ & 0.80 & 1.03 \\
\hline Commercial stations & $\begin{array}{l}\text { Number of commercial TV } \\
\text { stations in a station's market }\end{array}$ & 8.0 & 4.22 \\
\hline Public stations & $\begin{array}{l}\text { Number of public TV stations } \\
\text { in a station's market }\end{array}$ & 2.17 & 1.45 \\
\hline Cable penetration & $\begin{array}{l}\text { Cable penetration (\%) in a } \\
\text { station's market }\end{array}$ & 68.51 & 9.55 \\
\hline Public TV viewing & $\begin{array}{l}\text { Percentage of public TV viewing } \\
\text { in a station's market }\end{array}$ & 1.85 & 9.55 \\
\hline Nonbroadcast viewing & $\begin{array}{l}\text { Percentage of nonbroadcast } \\
\text { TV viewing in a station's market }\end{array}$ & 50.79 & 9.43 \\
\hline \% White & $\begin{array}{l}\text { Percentage of White population } \\
\text { in a station's market }\end{array}$ & 78.13 & 12.86 \\
\hline
\end{tabular}

Note: Dates are for 2003 unless otherwise indicated. Summary statistics are based on 221 commercial stations included in the regression analyses. 
public affairs programming provision in light of such programming's traditional status as an indicator of a station's commitment to localism.

In constructing these dependent variables, this study relied primarily on the program-type classifications utilized by the commercial data provider. This approach reflects the predominant approach utilized and relied upon by policy makers, who have shown a tendency to conduct and utilize analyses that rely upon the preestablished content classifications developed by the commercial providers of the data utilized in the analyses (e.g., Einstein, 2002; Spavins et al., 2002).

Nonetheless, a verification process also was employed to address potential cases of misclassification (e.g., when a program classified as local appeared in the schedules of stations in different markets, or when the title or program description data provided a clear indication that the program might not be a public affairs program). In these cases of uncertainty, station Web sites were consulted and/or the stations were called directly in order to ascertain the nature of the program. Relatively few misclassifications were identified and corrected as a result of this process. Specifically, 74 of the 3,118 programs categorized as public affairs programs were wrongly classified as such $(2.37 \%)$. In these instances, programs that were in fact restaurantreview programs, sports programs, infomercials, or news programs were labeled as public affairs and were thus removed from the data set. In addition, 167 of the 1,092 public affairs programs identified as local public affairs programs were misclassified and were in fact nonlocal public affairs programs (15.29\%), and 134 of the 2,026 programs categorized as nonlocal public affairs programs were in fact local public affairs programs $(6.61 \%)$. The data set was altered accordingly to reflect these corrections. It is unclear at this point whether this approach might lead to an overstating or an understating of public affairs programming, in comparison to results obtained via systematic content analysis, though this is an issue that should be addressed in future research.

\section{Results}

Local public affairs programming on broadcast television

Looking first at descriptive data on station provision of local public affairs programming, 143 stations (50\% of the 285 stations sampled) aired some local public affairs programs during the 2 -week sample period in 2003. Among the 233 commercial stations in the sample, $96(41 \%)$ aired some local public affairs programming. In contrast, 47 of the $52(90 \%)$ public television stations aired local public affairs programming during the sample period $\left(\chi^{2}=121.97, p<.001\right)$.

The sample stations averaged 1 hour 44 minutes of local public affairs programming during the 2-week sample period. However, public stations aired significantly more such programming than commercial stations, broadcasting over 6 hours of local public affairs programming, compared to the commercial stations' average of 45 minutes of such programming $(F=155.7, p<.05)$. A substantial difference also was exhibited between network-affiliated and independent stations, with 
network-affiliated stations providing an average of about 37 minutes of local public affairs programming, compared with an average of 110 minutes from independent stations $(F=13.21, p<.05)$.

\section{Regression results}

The regression analysis estimated the relationship between market competition and station ownership patterns and the quantity of local public affairs programming provision, using the 233 commercial stations in the sample. Twelve stations did not have station revenue data and had to be excluded from the regression analyses. Nearly $60 \%$ of the commercial stations did not air any local public affairs programming during the sample period. In addition, the dependent variable in the sample, local public affairs, is overdispersed, with its standard deviation significantly larger than its mean (see Table 1). For the estimation, the zero-inflated negative binomial (ZINB) model was used to deal with the excessive number of zeros and overdispersion observed in the dependent variable (Long, 1997).

The ZINB model was used for substantive reasons as well. Specifically, the zeros of the dependent variable may come from two different data-generating processes. First, some stations would never air any local public affairs programming due to the lack of production facility or some other unobserved reasons. For stations in this "always-zero" group, the probability of having a zero for the local public affairs variable is 1 . Other stations would air some local public affairs programs but happened to have aired none during the sample period. For the stations in this "zeroby-chance" group, the probability of having zero value is determined by the same data-generating process that governs the positive values, in this study, a negative binomial (NB) process. Therefore, the overall probability of zeros is a combination of the probabilities of zeros from each group, weighted by the probability of an individual station being in that group. A zero-inflated model estimates simultaneously how station and market variables are related to (a) the probability of a station falling in one of the two groups (the logit model in Table 2) and (b) the actual amount of local public affairs programming for those stations belonging to the second group (the NB model in Table 2). ${ }^{3}$

First, the logit portion of the ZINB model indicates how the various station ownership and market competition variables are related to the probability of a station being in the always-zero group. Considering first RQ 1, which addressed the possible relationship between competitive conditions in the market and station provision of local public affairs programming, the negative coefficient for the commercial stations variable indicates that stations in markets with a larger number of commercial stations are more likely to offer any local public affairs programming. No other independent variables related to the competitive conditions in a station's market (number of public television stations, cable penetration, public television viewing, or other nonbroadcast viewing) were significantly related to whether a station offered any local public affairs programming. 
Table 2 Zero-Inflated Negative Binomial Regression Results (dependent variable = local public affairs programming minutes; $N=221$ )

\begin{tabular}{|c|c|c|c|c|}
\hline & \multicolumn{2}{|l|}{ Logit } & \multicolumn{2}{|l|}{ NB } \\
\hline & $\gamma$ & $Z$ & $\beta$ & $Z$ \\
\hline Intercept & 4.43 & 1.90 & 5.62 & 4.26 \\
\hline VHF/UHF & -0.85 & $-2.20^{*}$ & 0.31 & 1.26 \\
\hline Station revenues & -0.01 & -1.46 & 0.00 & 0.23 \\
\hline Big Four affiliate & 0.15 & 0.34 & -0.38 & -1.42 \\
\hline Duopoly ownership & -0.38 & -0.85 & -0.28 & -1.34 \\
\hline Local ownership & -0.74 & -1.76 & -0.28 & -1.33 \\
\hline Big Four ownership & 2.31 & $3.12^{\star *}$ & -0.97 & $-3.05^{\star *}$ \\
\hline National audience reach & -3.19 & $-2.57^{\star *}$ & 0.05 & 0.09 \\
\hline TV households & 0.89 & $2.60^{\star *}$ & 0.26 & 1.36 \\
\hline Commercial stations & -0.27 & $-3.17^{\star \star}$ & -0.07 & -1.91 \\
\hline Public stations & 0.05 & 0.40 & 0.12 & 1.77 \\
\hline Cable penetration & -0.00 & -0.13 & 0.00 & 0.15 \\
\hline Public TV viewing & -0.19 & -1.21 & 0.04 & 0.47 \\
\hline Nonbroadcast TV viewing & -0.04 & -1.30 & -0.01 & -0.46 \\
\hline$\%$ White & 0.01 & 0.46 & -0.01 & -0.87 \\
\hline
\end{tabular}

Note: $\mathrm{NB}=$ negative binomial. Log likelihood $=-632.802$.

${ }^{\star}$ Significant at .05 level. ${ }^{\star}$ Significant at .01 level.

In terms of RQ 2, which addressed the relationship between ownership characteristics and the provision of local public affairs programming, the negative coefficient for national audience reach suggests that stations owned by larger station groups (in terms of the percentage of the national television audience reached by the owner's stations) are more likely to offer any local public affairs programming. In contrast, ownership by one of the Big Four broadcast networks was significantly negatively related to the likelihood of a station offering any local public affairs programming. The other ownership-related independent variables accounted for in the model (duopoly ownership and local ownership) were not significant at the .05 level.

In addition, the VHF/UHF control variable was positively related to the likelihood of a station offering local public affairs programming (with VHF stations more likely than their UHF counterparts to offer such programming), whereas the market size control variable was negatively related to the likelihood of a station offering any local public affairs programming, indicating that stations in larger markets are less likely to offer any local public affairs programming.

Turning next to the NB portion of the regression model, in terms of RQ 1, none of the market competition-related independent variables were significantly related to the quantity of local public affairs programming provided by a station. In terms of RQ 2, ownership by a Big Four network was significantly negatively related to the quantity of local public affairs programming offered by a station, following the similarly negative relationship found in terms of a station's likelihood of offering 
any local public affairs programming. As was the case in the logit portion of the model, no other ownership-related independent variables were significantly related to the quantity of local public affairs programming provided by a station. None of the control variables incorporated into the model were significantly related to the quantity of local public affairs programming provided by a station.

\section{Conclusions}

This study has presented descriptive data on broadcast television stations' provision of local public affairs programming and has investigated economic theory and localism theory perspectives on the factors likely to affect the provision of such programming. The descriptive data have shown that half of the stations in the sample did not air any local public affairs programming during the 2-week sample period in 2003. For commercial stations, this figure is $59 \%$. On average, a commercial station aired about 45 minutes of local public affairs programming during the 2 weeks, or less than half an hour per week. Although there exists no a priori standard for the adequacy of local public affairs programming on television, the fact that stations offer, on average, less than one complete program per week suggests that the amount of time that commercial stations devote to this type of programming is insufficient. In contrast, the vast majority of the public stations in the sample (about 90\%) aired some local public affairs programming during the sample period. On average, they broadcast about 3.5 hours of said programming per week. It would seem, then, that the commercial imperatives of ad-supported broadcast television inhibit the production of local public affairs programming and that these results suggest that commercial broadcasters are ceding public affairs programming to their noncommercial counterparts. This sort of division of the programming market certainly makes sense from a strategic standpoint but does become problematic when we consider the declining level of governmental support for public television. If public television is to be the primary source for broadcast public affairs-a key component of the type of informational programming deemed important to the public interest and broadcasters' contribution to the democratic process-then for that type of programming to increasingly migrate to outlets that are in an increasingly precarious financial position represents a scenario that policy makers should be concerned about.

Turning to the multivariate analyses, in terms of RQ 1 , the results provide limited support for the marketplace theory logic that greater competition in media markets will compel the production of programming such as local public affairs. The results indicate a positive relationship between the number of commercial stations in a market and a commercial station's probability of airing any local affairs programming; however, no such relationship existed in terms of the quantity of programming provided. None of the other indicators of competitive conditions in a station's market were significantly related to the availability and amount of local public affairs programming provided. Although it may be the case that markets with more outlets 
will, as a whole, offer a greater overall quantity of such programming (given the larger number of available outlets; see Napoli, 2001c), the notion that increased competition will spur individual stations to provide such programming appears unlikely. Rather, as the descriptive data suggest, commercial broadcast stations may be more likely to cede the local public affairs programming market to their noncommercial counterparts and perhaps ultimately local cable as well (future research should more thoroughly account for the availability of local public affairs programming on local cable systems). Moreover, to the extent that the quantity of outlets in a market is a function of the size of the market (in terms of the number of television households), this study's finding that stations in larger television markets were less likely to be in the business of offering local public affairs programming suggests further that marketplace incentives for the provision of local public affairs programming are weak at best. Overall, these results are in line with those of other recent studies (e.g., Napoli, 2001b, 2002) that found that competitive conditions provide incentives for the provision of local public affairs programming that are weak at best.

The results are similarly mixed in terms of RQ 2. The economies of scale logic receives some support from the fact that the station ownership group size was positively related to a station's likelihood of offering any local public affairs programming, though this variable bore no relationship to the quantity of local public affairs programming provided by a station. More consistent were the results for Big Four network ownership, which were significantly negatively related to both a station's decision to air any local public affairs programming and to the quantity of such a programming provided by a station. The Big Four-owned stations generally have more resources, but their financial importance to their network parent may discourage them from taking the risk in providing local public affairs programming (given that the station business has been the cash cow for the networks, with the network business consistently losing money). The opportunity costs may simply be too high. Somewhat surprisingly, the ownership characteristic that would seem most likely to produce the economies of scale capable of encouraging greater local public affairs program production-duopoly ownership—was not significant in either model.

In the end, these findings call into question one of the commonly articulated rationales for more relaxed national and multiple ownership rules- that of economies of scale associated with the relaxation of ownership limits contributing to improved public service in the form of informational programming (see also Napoli \& Yan, in press). The chronically low level of local public affairs programming on television, despite drastic changes in local media market in recent years, and the lack of strong positive relationships between competitive and ownership conditions illustrated in this study, suggest that policies purporting to promote the provision of such programming that are premised upon market incentives or the relaxation of ownership structure limits are unlikely to be effective.

From a localism standpoint, these results confirm some of the criticisms leveled specifically at network owners (Network Affiliated Stations Alliance, 2001); however, 
it is also important to note that the local ownership variable was not significantly related to local public affairs programming provision, undermining support for the assertion that locally owned stations will serve their communities better in the form of more local public affairs programming. In this regard, advocacy of local ownership of broadcast outlets that is premised on the notion that such owners will serve their communities better by providing more informational programming, such as local public affairs, would appear to lack a strong empirical grounding. Given this combination of results, policy makers seeking to preserve and promote the provision of local public affairs programming may need to consider revisiting explicit behavioral obligations as a regulatory instrument.

These conclusions should, of course, be tempered by the fact that the quantity of local public affairs programming represents only one mechanism by which a broadcast station can demonstrate its commitment to serving the informational needs and interests of the local community. Other program categories, such as local news and public service announcements also are relevant. In addition, program quantity is itself a somewhat limited measure. Future research may seek to examine the content of such programming in terms of the extent that the programming is indeed devoted to issues that are "local" in nature and to issues that meet generally accepted criteria for "public affairs."

\section{Acknowledgments}

This research was supported by grants from the Ford Foundation's Media, Arts, and Culture Unit, Fordham University's Graduate School of Business Summer Research Grant Program, and the Howard R. Marsh Center in the Department of Communication Studies at the University of Michigan. The authors thank David Gastwirth of Duke University for his research assistance on this project.

\section{Notes}

1 "Sweeps" months (November, February, May, and July) are when all 210 television markets in the United States are measured by Nielsen Media Research. During these periods, stations often employ particularly aggressive or sensationalistic programming strategies in order to maximize ratings (see Ehrlich, 1995).

2 Of the four deleted stations, two have incomplete programming data and the other two turned out to be religious stations.

3 Let the probability of a station being in the always-zero group be $\varphi$ and in the zero-bychance group $1-\varphi$ and assume that the value of $\varphi$ is determined by some explanatory variables $z$, that is, $\varphi_{i}=F\left(z_{i} \gamma\right)$. When the process governing the distribution of counts in the second group is specified to be Poisson, we have a zero-inflated Poisson (ZIP) model.

$$
\operatorname{OPr}\left(y_{i} \mid x_{i}, z_{i}\right)=\varphi_{i}+\left(1-\varphi_{i}\right) \frac{\mathrm{Oe}^{-\mu_{i}} \mu_{i}^{y_{i}}}{y_{i} !}
$$

where 


$$
\begin{gathered}
\operatorname{OPr}\left(y_{i}=0 \mid x_{i}, z_{i}\right)=\varphi_{i}+\left(1-\varphi_{i}\right) \mathrm{e}^{-\mu_{i}} \\
\operatorname{OPr}\left(y_{i} \mid x_{i}, z_{i}\right)=\left(1-\varphi_{i}\right) \frac{\mathrm{Oe}^{-\mu_{i}} \mu_{i}^{y_{i}}}{y_{i} !} \quad \text { forO } y_{i}>0 \\
\mu_{i}=\operatorname{Oexp}\left(x_{i} \beta\right) .
\end{gathered}
$$

Alternatively, an NB process can be specified to control for overdispersion and unobserved heterogeneity in the dependent variable, as in the current study. We then have a ZINB model with the following probability density function:

$$
\operatorname{OPr}\left(y_{i} \mid x_{i}, z_{i}\right)=\varphi_{i}+\left(1-\varphi_{i}\right) \frac{\Gamma\left(y_{i}+v_{i}\right)}{y_{i} ! \Gamma\left(v_{i}\right)}\left(\frac{v_{i}}{v_{i}+\mu_{i}}\right)^{v_{i}}\left(\frac{\mu_{i}}{v_{i}+\mu_{i}}\right)^{y_{i}}
$$

where

$$
\begin{gathered}
\operatorname{OPr}\left(y_{i}=0 \mid x_{i}, z_{i}\right)=\varphi_{i}+\left(1-\varphi_{i}\right)\left(1+\alpha \mu_{i}\right)^{-\alpha^{-1}} \\
\operatorname{OPr}\left(y_{i} \mid x_{i}, z_{i}\right)=\left(1-\varphi_{i}\right) \frac{\Gamma\left(y_{i}+\alpha^{-1}\right)}{y_{i} ! \Gamma\left(\alpha^{-1}\right)}\left(\frac{\alpha^{-1}}{\alpha^{-1}+\mu_{i}}\right)^{\alpha^{-1}}\left(\frac{\mu_{i}}{\alpha^{-1}+\mu_{i}}\right)^{y_{i}} \quad \text { forO } y_{i}>0
\end{gathered}
$$

$\alpha$ is a dispersion parameter and represents the extent to which the observed data are overor underdispersed. For the current study, $\alpha=.476$ and is significantly different from zero (Wald $Z=4.22, p=.000$ ), indicating overdispersion. This, plus the institutional characteristics of the study, explains why the ZINB model was used instead of the ZIP model. In addition, the distribution of $F\left(z_{i} \gamma\right)$ was assumed to be logit and the $z$ s were the same as the $x \mathrm{~s}$ in the current study. For a detailed discussion of the zero-modified models and examples, see Long (1997, chap. 8).

\section{References}

BIA Research. (2003a). Investing in television market report. Chantilly, VA: Author.

BIA Research. (2003b). Investing in television ownership file. Chantilly, VA: Author.

Bishop, R., \& Hakanen, E. A. (2002). In the public interest? The state of local television programming fifteen years after deregulation. Journal of Communication Inquiry, 26, 261-276.

Chamberlin, B. F. (1979). The impact of public-affairs programming regulation: A study of the FCC's effectiveness. Journal of Broadcasting, 23, 197-212.

Crandall, R. (2003). The economic impact of providing service to multiple local broadcast stations within a single geographic market, attached to comments of Sinclair Broadcasting. In the matter of 2002 biennial regulatory review. Retrieved December 1, 2005, from http://www.criterioneconomics.com/docs/multiple_local_bcst_stns.pdf

Ehrlich, M. C. (1995). The ethical dilemma of television news sweeps. Journal of Mass Media Ethics, 10(1), 37-47.

Einstein, M. (2002). Program diversity and the program selection process on broadcast network television. Washington, DC: Federal Communications Commission. 
Entman, R. M., \& Wildman, S. S. (1992). Reconciling economic and non-economic perspectives on media policy: Transcending the "marketplace of ideas." Journal of Communication, 41, 5-19.

Federal Communications Commission. (1976). Amendment to Section 0.281 of the Commission's rules: Delegations of authority to the Chief, Broadcast Bureau. 59 FCC 2d 491.

Federal Communications Commission. (1984). Revision of programming and commercialization policies, ascertainment requirements, and program log requirements for commercial television stations, 1984 FCC LEXIS 2105.

Federal Communications Commission. (1999a). The public and broadcasting. Report prepared by the Mass Media Bureau. Washington, DC: Federal Communications Commission.

Federal Communications Commission. (1999b). Public interest obligations of TV broadcast licensees, 1999 FCC LEXIS 6487.

Federal Communications Commission. (1999c). Report and order. Retrieved March 29, 2004, from http://ftp.fcc.gov/Bureaus/Mass_Media/Orders/1999/fcc99209.pdf

Federal Communications Commission. (2002). 2002 biennial regulatory review. Notice of Proposed Rule Making, 17 FCC Rcd. 18503.

Federal Communications Commission. (2003). 2002 biennial regulatory review. Report and Order and Notice of Proposed Rulemaking, 18 FCC Rcd. 13620.

Federal Communications Commission. (2004). Broadcast localism. Notice of Inquiry, 19 FCC Rcd. 12425.

Fowler, M. S., \& Brenner, D. L. (1982). A marketplace approach to broadcast regulation. Texas Law Review, 60(2), 207-257.

Hamilton, J. T. (2004). All the news that's fit to sell: How the market transforms information into news. Princeton, NJ: Princeton University Press.

Karmazin, M. (2001, July 17). Statement before the Senate Commerce Committee. Retrieved October 5, 2005, from http://commerce.senate.gov/hearings/071701Karmizan.pdf

Kunkel, D. (1998). Policy battles over defining children's educational television. Annals of the American Academy of Political and Social Sciences, 557, 39-53.

Long, J. S. (1997). Regression models for categorical and limited dependent variables. Thousand Oaks, CA: Sage.

Napoli, P. M. (1997). A principal-agent approach to the study of media organizations: Toward a theory of the media firm. Political Communication, 14, 207-219.

Napoli, P. M. (2001a). Foundations of communications policy: Principles and process in the regulation of electronic media. Cresskill, NJ: Hampton Press.

Napoli, P. M. (2001b). Market conditions and public-affairs programming: Implications for digital television policy. Harvard International Journal of Press/Politics, 6(2), 15-29.

Napoli, P. M. (2001c). Social responsibility and commercial broadcast television: An assessment of public-affairs programming. International Journal on Media Management, 3, 226-233.

Napoli, P. M. (2002, August). Television station ownership characteristics and commitment to public service: An analysis of public-affairs programming. Paper presented at the annual meeting of the Association for Education in Journalism and Mass Communication, Miami, FL.

Napoli, P. M. (2004). Television station ownership characteristics and news and public-affairs programming: An expanded analysis of FCC data. Info: The Journal of Policy, Regulation, and Strategy for Telecommunications, Information, and Media, 6(2), 112-121. 
Napoli, P. M., \& Yan, M. Z. (in press). Media ownership regulations and local news programming on broadcast television: An empirical analysis. Journal of Broadcasting and Electronic Media.

Network Affiliated Stations Alliance. (2001). Petition for inquiry into network practices. Retrieved September 15, 2004, from http://www.networkaffiliatedstations.org/ 3-8-01NASAPETITIONFORINQUIRY.pdf

Owen, B. M., \& Wildman, S. S. (1992). Video economics. Cambridge, MA: Harvard University Press.

Powers, A. (2001). Toward monopolistic competition in U.S. local television news. Journal of Media Economics, 14(2), 77-86.

Prometheus Radio Project v. Federal Communications Commission, 373 F.3d 372 (2004).

Ryan, S. C. (2001, October 23). Local program cutbacks are a sign of the times. Boston Globe, pp. E1, E7.

Singleton, L. A, \& Rockwell, S. C. (2003). Silent voices: Analyzing the FCC "media voices" criteria limiting local radio-television cross-ownership. Communication Law and Policy, 8, 385-403.

Spavins, T. C., Denison, L., Roberts, S., \& Frenette, J. (2002). The measurement of local television news and public affairs programs. Washington, DC: Federal Communications Commission.

Wirth, M. O., \& Wollert, J. A. (1978). Public interest programming: FCC standards and station performance. Journalism Quarterly, 55, 554-561.

Wirth, M. O., \& Wollert, J. A. (1979). Public interest programming: Taxation by regulation. Journal of Broadcasting, 23, 319-330. 